\title{
展伸用アルミニウムの結晶粒微細化剂と研究部会共通試料
}

\author{
白井 孝太 $^{1 *}$. 石渡 保生 $^{1} \cdot$ 勝亦 秀明 $^{2}$
}

Journal of The Japan Institute of Light Metals, Vol. 71, No. 1 (2021), 30-31

(C) 2021 The Japan Institute of Light Metals

\section{Aluminum grain refiner for wrought material and common sample for research group}

\author{
Kota SHIRAI $^{1 *}$, Yasuo ISHIWATA ${ }^{1}$ and Hideaki KATSUMATA ${ }^{2}$
}

Keywords: grain refiner; DC casting

\section{1. はじめに}

アルミニウム合金を製造する際，鋳造時の割れ防止や，熱 間加工性の向上，表面処理の外観不良低減，機械的特性の向 上などを目的として，鋳造組織の結晶粒微細化が行われる。 結晶粒微細化の最も一般的な方法は, $\alpha-\mathrm{Al}$ 相の凝固核となる 異質核を添加する方法であり，異質核となる粒子は次の条件 を満たす必要がある ${ }^{1)}$ 。

・密度がアルミニウム溶湯とほぼ等しいこと

・短時間ではアルミニウム溶湯や溶質元素と反応しにくい こと

・鋳造温度で溶解せず熱的に安定であること

・凝集傾向が低いこと

$\cdot \alpha-\mathrm{Al}$ 相との整合性が高いこと

$\cdot \alpha-\mathrm{A} 1$ 相との界面エネルギーが低いこと

・アルミニウム溶湯との界面エネルギーが低いこと

これらの要求を満たす粒子として $\mathrm{Al}_{3} \mathrm{Ti}, \mathrm{TiB}_{2}, \mathrm{TiC}$ 等が知 られており,これらの粒子を含むAl-Ti合金, Al-Ti-B 合金, Al-Ti-C 合金等がアルミニウム合金の微細化剂として市販さ れている。市販されている合金種を Table 1 に示す（表中の

Table 1 Commercially available aluminum grain refiner alloys.

\begin{tabular}{l|l}
\hline \hline \multicolumn{1}{c|}{ Alloy type } & \multicolumn{1}{c}{ Composition } \\
\hline Al-Ti & Al-6Ti \\
& Al-10Ti \\
\hline Al-Ti-B & Al-1.6Ti-1.4B \\
& Al-3Ti-1B \\
& Al-5Ti-0.1B \\
& Al-5Ti-0.2B \\
& Al-5Ti-1B \\
\hline Al-Ti-C & Al-3Ti-0.15C \\
\hline
\end{tabular}

Al-XTi等はAl-Xmass\%Ti等を表す)。またこれらの微細化剂 はコイル，ワッフル，バーなどの形状で市販されている。

アルミニウム展伸材の製造現場で最も一般的な方法はコイ ル形状の Al-Ti-B 合金を樋で溶湯に連続的に添加する方法で ある。Al-Ti-B合金の場合， $\mathrm{TiB}_{2}$ が異質核であるがそれ自体は $\alpha-\mathrm{Al}$ 相との整合性は高くない。 $\mathrm{TiB}_{2}$ の表面に $\mathrm{Al}_{3} \mathrm{Ti}$ が生成する ことで， $\alpha-\mathrm{Al}$ 相との整合性が高まり異質核として働くことが 知られている。

しかしジルコニウムを含有するアルミニウム合金を鋳造す る場合，Al-Ti-B 合金では微細化されないことが知られてい る。これはジルコニウムが $\mathrm{TiB}_{2}$ 表面での $\mathrm{Al}_{3} \mathrm{Ti}$ の生成を阻害 するためと考えられている。そこでAl-Ti-B合金の代わりに Al-Ti-C 合金を使用するのが一般的である。

\section{2. 研究部会共通試料の化学成分および内部組織}

アルミニウムの凝固・微細化・清净化研究部会では, 「結 晶粒微細化」について微細化能評価方法の基準化や微細化プ ロセスの解明を目的に各種の試験を実施した。試験の共通試 料を選定するために軽圧各社へアンケートを行い, 最も使用 が多かったA社製の Al-5Ti-1B 合金（ $\phi 9.5 \mathrm{~mm}$ コイル形状）を 共通試料として購入した。また微細化浏メーカーごとに微細 化能が変動するとの意見もあったため, B 社製および $\mathrm{C}$ 社製 (グレードA， B ）の Al-5Ti-1B合金（ $\phi 9.5 \mathrm{~mm}$ コイルからの切 断片）も比較材として入手した。これらについて性状を明確

Table 2 Chemical composition (mass\%).

\begin{tabular}{c|c|c|c|c|c}
\hline \hline & $\mathrm{Ti}$ & $\mathrm{B}$ & $\mathrm{V}$ & $\mathrm{Si}$ & $\mathrm{Fe}$ \\
\hline $\mathrm{A}$ & 5.0 & 1.1 & 0.01 & 0.08 & 0.10 \\
$\mathrm{~B}$ & 4.9 & 1.0 & 0.01 & 0.08 & 0.13 \\
C Grade-A & 5.0 & 1.1 & 0.01 & 0.05 & 0.12 \\
C Grade-B & 4.9 & 1.1 & 0.01 & 0.06 & 0.13 \\
\hline
\end{tabular}

\footnotetext{
${ }^{1}$ 日本軽金属株式会社（广421-3291 静岡県静岡市清水区蒲原 1-34-1） Nippon Light Metal Company, Ltd. (1-34-1 Kambara, Shimizu-ku, Shizuokashi, Shizuoka 421-3291)

2 三菱アルミニウム株式会社（裾野市） Mitsubishi Aluminum Co.,Ltd.（Susono-shi, Shizuoka）

*責任著者E-mail：kota-shirai@nikkeikin.co.jp

受付日：2020年7月 17 日 受理日：2020年9月24日
} 

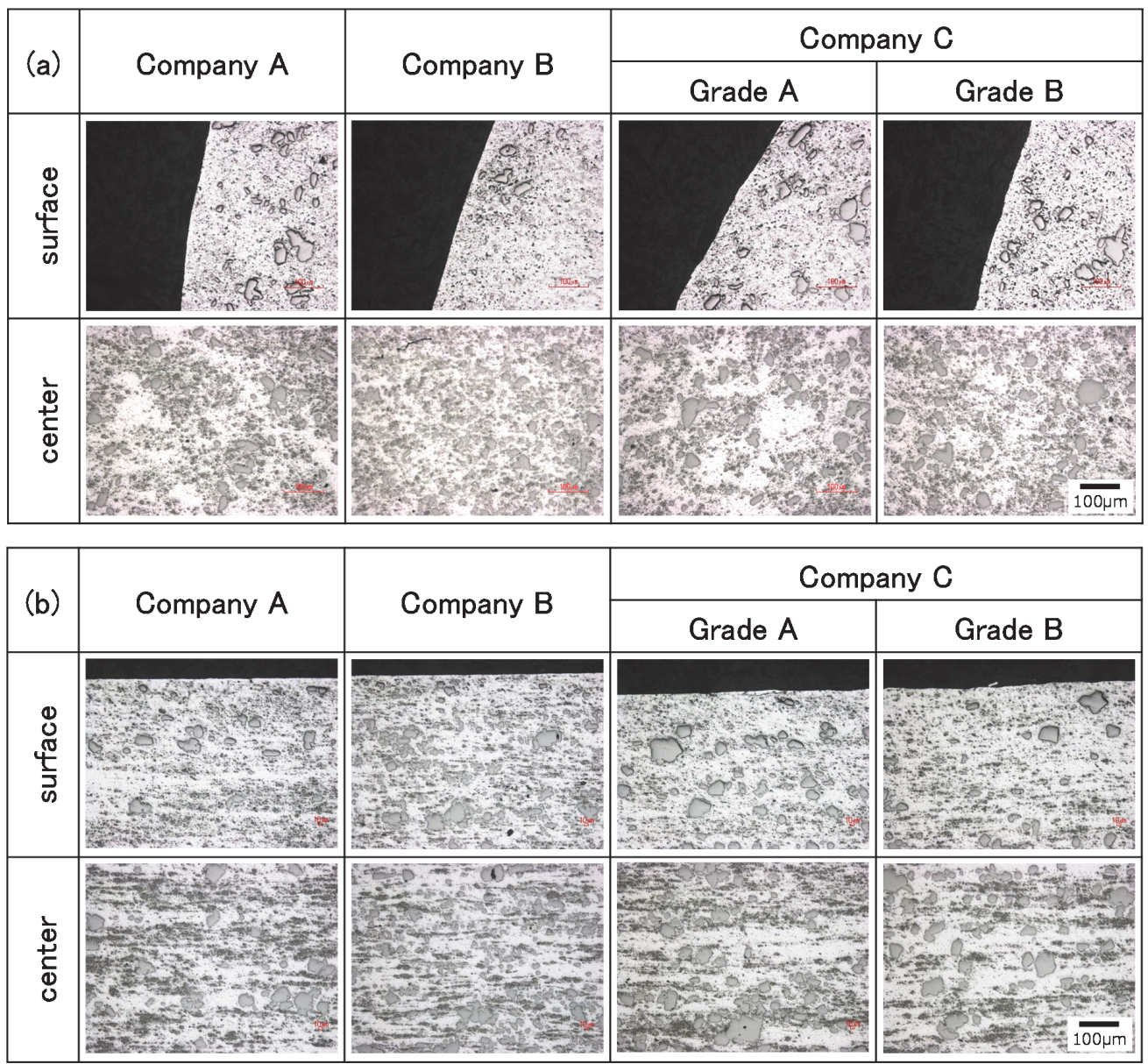

Fig. 1 Observation of microstructure by optical microscope. (a) Cross section perpendicular to the longitudinal direction. (b) Cross section parallel to the longitudinal direction.

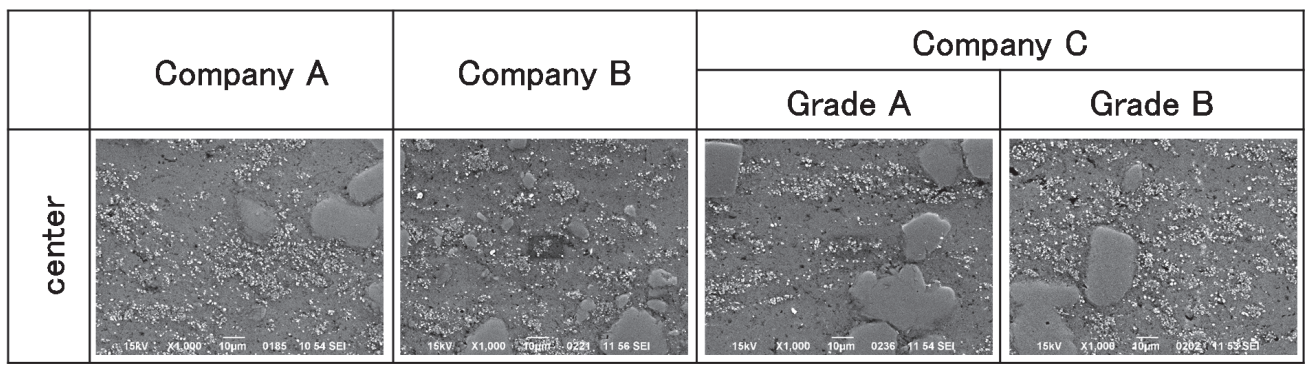

Fig. 2 Observation of microstructure by SEM.

にするため，化学組成および内部組織を調査した。

まず化学組成の分析を実施した。共通試料および比較材の コイル形状片を酸分解により溶液化し, 誘導結合プラズマ発光 分光分析法（ICP-OES）にて定量分析を行った。この分析結果 を Table 2 に示す。異質核生成の添加元素であるチタン，ボロ ンの定量結果に含有量差は認められなかった。また, ケイ素, 鉄の定量結果からいずれのサンプルもベースとなるアルミニ ウム原料はP1020グレード相当を使用していると考えられる。

次に内部組織を観察した。機械研磨にて鏡面に仕上げた 後，光学顕微鏡およびSEMで観察を行った。またEDSによる 第二相粒子の点分析も実施した。光学顕微鏡では長手方向に 垂直な断面および平行な断面，SEMでは長手方向に垂直な断 面で観察を実施した。光学顕微鏡の観察結果をFig. 1 に, SEMの観察結果をFig. 2 に示す。いずれのサンプルも数 $10 \mu \mathrm{m}$ と約 $1 \mu \mathrm{m}$ の第二相粒子が存在しており，第二相粒子のSEM-
$\mathrm{EDS}$ 分析より, 数 $10 \mu \mathrm{m}$ の粒子は $\mathrm{Al}_{3} \mathrm{Ti}$, 約 $1 \mu \mathrm{m}$ の粒子は $\mathrm{TiB}_{2}$ と考えられた。また $\mathrm{TiB}_{2}$ は数 $100 \mu \mathrm{m}$ オーダーで疎密な領域が 存在しており, その疎密な領域は長手方向へ伸びた組織に なっていた。B社製およびC社製（グレード $\mathrm{A} ， \mathrm{~B}$ ）は表層付 近でポロシティが比較的多く観察された。

\section{3. まと め}

アルミニウムの結晶粒微細化剂について一般論を記し，ア ルミニウムの凝固・微細化・清浄化研究部会での共通試料お よび比較材について, 化学組成の分析および内部組織の結果 を示した。研究部会ではこの共通試料を用いて各種の検討を 実施した。

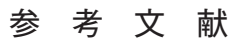

1) J.D.Schloz: LIGHT METAL AGE, 8 (2010), 30-37. 